\title{
Economic price determination of technological products for market entry considering the concept of uncertainty
}

Farbod Ketabchi, Master of Science in Management of Technology (MOT), Iran University of Science and Technology, Tehran, Iran.

Ketabchi@alumni.iust.ac.ir

Saeed Yaghoubi, Assistant Professor, Department of Industrial Engineering, Iran University of Science and Technology, Tehran, Iran.

Yaghoubi@iust.ac.ir

Seyed Omid Hashemi Amiri, Master of Science in Industrial Engineering, Iran University of Science and Technology, Tehran, Iran.

Omid_hashemi@alumni.iust.ac.ir

Mohsen Maleki, Master of Science in Industrial Engineering, Caspian Higher Education Institute, Qazvin, Iran.

Maleki.mohsen91@gmail.com

\section{Editor Científico: José Edson Lara}

Organização Comitê Científico

Double Blind Review pelo SEER/OJS

Recebido em 10.06.2019

Aprovado em 08.11.2019 


\begin{abstract}
One of the important issues regarding pricing is the type of customers. If so, we must answer this question: Is the attitude of customers the same when they face the price of products or act differently? It is the premise of the work that in most cases the reaction of customers is different when they come across the price. That is why it is necessary to segment the market and adopt price flexibility. Thus, this research presents a mathematical model to explain the sale price of technological products in a chain store unit. In the process of choosing and buying, the concern with the queue is understandable if the customer is researching and comparing location and prices, affecting the effectiveness and efficiency of the sale. For this research, a mathematical pricing model is proposed according to the pricing form of the agencies in an exclusive market of technological products. It is presented for a stable situation, and aims to expand the model to unrealistic situations, approaching real situations. It is developed with the help of Mulvey's stable model in unfix condition and will be developed on the basis of the literature on this topic.
\end{abstract}

Key words: Economic price; Technological products; Branch pricing; Exclusive selling; Theory of queue; Instability; Stable model of Mulvey.

\title{
Determinação do preço econômico de produtos tecnológicos para entrada no mercado
}

\section{considerando o conceito de incerteza}

\section{Resumo}

Uma das questões importantes em relação aos preços é o tipo de clientes. Nesse caso devemos responder a esta pergunta: a atitude dos clientes é a mesma quando eles enfrentam o preço dos produtos ou agem de forma diferente? É premissa do trabalho que na maioria dos casos a reação dos clientes é diferente, quando eles se deparam com o preço. Por isso é necessário segmentar o mercado e adotar flexibilidade nos preços. Assim, esta pesquisa apresenta um modelo matemático para explicar o preço de venda de produtos tecnológicos em uma unidade de rede de lojas. No processo de escolha e compra a preocupação com a fila é compreensível se o cliente estiver pesquisando e comparando localização e preços, afetando a eficácia e a eficiência da venda. Para esta pesquisa, propõe-se um modelo matemático de precificação de acordo com a forma de precificação das agências em um mercado exclusivo de produtos tecnológicos. É apresentado para uma situação estável, e tem a finalidade de expandir o modelo para situações irreais, aproximando de situações reais. É desenvolvido com a ajuda de modelo estável de Mulvey na condição de unfix e será desenvolvido na base na literatura deste tema.

Palavras-chave: Preço econômico; Produtos tecnológicos; Preços de filial; Venda exclusiva; Teoria da fila; Instabilidade; Modelo estável de Mulvey. 


\section{Determinación del precio económico de productos tecnológicos para la comercialización considerando el concepto de incertidumbre}

\section{Resumen}

Una de las cuestiones importantes con respecto a los precios es el tipo de clientes. Si es así, debemos responder a esta pregunta: ¿Es la actitud de los clientes la misma cuando enfrentan el precio de los productos o actúan de manera diferente? La premisa del trabajo es que, en la mayoría de los casos, la reacción de los clientes es diferente cuando se encuentran con el precio. Por eso es necesario segmentar el mercado y adoptar flexibilidad de precios. Por lo tanto, esta investigación presenta un modelo matemático para explicar el precio de venta de productos tecnológicos en una unidad de cadena de tiendas. En el proceso de elegir y comprar, la preocupación con la cola es comprensible si el cliente está investigando y comparando la ubicación y los precios, lo que afecta la efectividad y la eficiencia de la venta. Para esta investigación, se propone un modelo matemático de precios de acuerdo con la forma de precios de las agencias en un mercado exclusivo de productos tecnológicos. Se presenta para una situación estable y tiene como objetivo ampliar el modelo a situaciones poco realistas, abordando situaciones reales. Se desarrolla con la ayuda del modelo estable de Mulvey en condiciones de no fijación y se desarrollará sobre la base de la literatura sobre este tema.

Palabras clave: precio económico; Productos tecnológicos; Precios de sucursal; Venta exclusiva Teoría de la cola; Inestabilidad; Modelo estable de Mulvey.

\section{1-Introduction}

The aim of issue is considering the essentiality of modeling and determining of different parameters for finding an optimal collection of areas also pricing of products in each area according to authorized scope of price in those areas in the instable condition, in a way that it maximizes the total profit (1). In the presented fixed model, the rate of demand for purchasing the product considered fixed, which in real situation this theory is far from reality. Because the rate of demand for a product depends on different issues such as season, technological developments, closeness to some especial times such as New Year.

In this research for the purpose of evaluation of the model in unfixed condition, we use the approach of stable modeling and Mulvey modeling (2-4).Another important point which is effective in markets is paying attention to the customers' need and providing a condition for saving time of reaching products (5). One of prominent time, is the time which the customers have to stay in queue, and whatever is clear is the length of the queue which if it is not normal, it causes losing of customers and reduction of system's profit. The subject of queue and its parameters which lack of them in finding location and pricing is understandable, which it affects the efficiency and effectiveness of selling. The entrance of this issue into researches causes its 
closeness to the real world and its efficiency (6). So in this present study, for increasing the lucrativeness of this issue, we consider it from the point of view of queue too. Technological productions are goods which in their producing process especial technology are used. So available products in market (especially products produced inside of country) cannot compete with them. It is considered as advantages which make the selling of these products exclusive, but from another point of view can be as a danger , because product has a new identity , and may be cannot be acceptable from technical point of view or other reasons by people .(7-10). From another side, because of freshness of these products, their prices should be determine precisely because high price causes losing the demand and low price decreases the profit . This topic explains the uncertain entrance way which is in this issue. In this research we are going to provide a model to maximize the rate of profit and from another side prevent decreasing of demands by having abnormal prices (11-15).

For this aim, the model of stable mode is used, and a location finding model for pricing on the base of way of branch pricing is presented in an exclusive market. By the help stable model which will develop in an uncertain condition, and it is considered as a new issue in the literature of subject on the base of studied library sources .Price should determine not only in a way that residents around that area be able to purchase the products but also it increases the profit too( 16-17). The issue of pricing and finding the location in the literature of subject in operation has rich experience, and lots of researches have been done. In most of these researches, presented models and effect of pricing in a frame of united model are not designated. These two aims are different on the base of their plans, while finding location is in the group of long term planning issues, pricing is in the group of midterm planning issues, but these two aims together have important role in increasing the income (18). The advantages of this research than the other similar ones, can mention to below points :

-In this research in comparison with the other similar researches, the approach of math modeling will be used, and it tries by using available hypothesis, considers pricing and instability in the frame of united model. Also the usage of stable modeling concept and developing of the issue in a not fixed condition in this branch, determines which how the topic of instability interferes in the subject of selling of technological productions. 
-In this research we considered the issue of queue, because of increasing the effectiveness and efficiency of selling which finally it results in profit for the organization and much satisfaction of customers.

-Using from an over creative method for solving presented model is another aspect of this research.

\section{2- Review of previous researches}

Since this studying considers the evaluation of modeling method and presenting suitable model for pricing of technological productions, so achieved results can be used for pricing of research projects and developing their usage also can be given to other researchers for developing planning and technology management. Also intermediate companies and managers of selling which are active in the branch of selling, can use from the results of this research.

There are lots of articles about pricing and income management too. As it is mentioned in classic models finding location and pricing were considered as predefined parameters, and they did not have important role in the variables of decision. It had lots of reasons which the most important one was planning related to pricing as a short term issue in opposed with location finding (19). Aboolean and collogues (2008) evaluated the model of location finding and pricing by using the theory of games, and in it tried to find the best strategy in the Stolkberge balance .Lederes (1990)in his article mentions that in the subject of location finding and pricing at first decision about location finding should be done and then pricing (21). As Hamjoul and his colleagues (2001)in their work evaluated this subject , concluded that decisions about finding locations and pricing always can't be done separately, for example in the cases that selecting of locations depends on the demands and it also depends on price(22). Research of Diakova and Kochetov(2014), which is the base model of this research, wanted to select determined number of potential areas for establishing equipment of a complex to maximize the whole income of the complex. They used the strategy of branch pricing. They wanted to find an optimal price ease of establishing separately. They considered customers' demand as a central matter in separate locations. In their research they defined the ability of each customer's purchase .And customers for achieving the products search a facility which has minimum expenses of trip and price of the products and at least for solving their own model, they used Algorithm of SA and VNS .(23) 


\section{3- Research Method and research questions}

In this research a location finding model and pricing will be presented, which in it, they have chosen areas which is capable for presenting the products or giving service and determining the price of servicing or selling for the product in a way that to have the highest level of profit. In the model of finding location and pricing in this research the chance of capable areas for election is equal with all those areas which in them there is demand for service and the product, and each of these areas according to the population and people's needs have clear rate of demands and sometimes different .Also in each area price according to the economic condition of people is defined. As it is told, the aim of the issue , is finding an optimal complex of area and also pricing of product or service in each area according to the acceptable price limitation in that area by increasing the whole profit of system . The type of selling will be exclusive and other opponents will not have any effect on the price of product. In all social systems, the issue of queue is considered as an effective and important matter which influences competence of selling. It is important in a way that if the subject of queue becomes problematic, the selling condition will face with danger. So in present issue increasing the profit and decreasing instability in selling of the product, the subject of queue also has been considered too. The questions in this research are as below:

1- Can we present mathematical model of pricing for technological products?

2- Can we use exclusive selling for determining the price of technological products?

3- How much should be the budget for branches for determining the price?

4- Which mathematical model should be used for increasing the price of product for

the aim of developing of the profit and determining the price from budget level of

customers which is not much for them?

\section{4-Model Introduction and method of solving}

\section{4-1 Introduction of Parameters, variables and model of issue}

According to the presented questions, parameters are as below Potential branches for establishing selling center i Customer's Andes 
The rate of area demand $j \quad Y_{j}$

The expenses of establishing branch in area $i \quad f_{i}$

The expenses of transportation from branch I to the $\quad c_{i j}$ customer j

The time of transportation from branch I to customer $j \quad t_{i j}$

The expenses of sending product from central storage $\quad c w_{i}$ to the area $\mathrm{i}$

The rate of giving service in the branch i $\quad \mu_{\mathrm{i}}$

The resident customer's budget in the area $j \quad B_{j}$

The maximum length of queue in branch $\mathrm{Z}$

The possibility of not passing from the maximum $\alpha$ acceptable queue length

Acceptable low level for pricing of the product in the $a_{i}$ area $\mathrm{i}$

Acceptable high level of for pricing of the product in area $\mathrm{i}$

Also the variables of the issue are as below:

Price in the area $\mathrm{i}$

The rate of entering to the area $\mathrm{i}$ or buying product or using the service

Accidental variable of length in queue in the branch

If the area $i$ is selected for establishing of branch

Unless

$$
y_{i}=\left\{\begin{array}{l}
1 \\
0
\end{array}\right.
$$

If the customer comes from the area $\mathrm{j}$ for getting product of service Unless 
According to points mentioned in top, the mathematical model is presented as below:

$1 \quad \operatorname{maxz}=\sum_{\mathrm{i}} \mathrm{p}_{\mathrm{i}} \lambda_{\mathrm{i}}-\sum_{\mathrm{i}} \mathrm{f}_{\mathrm{i}} \mathrm{y}_{\mathrm{i}}-\sum_{i} c w_{i} y_{i}$

$2 \sum_{i} x_{i j} \leq 1$

$j=1,2, \ldots, n$

$3 \quad y_{i} \geq x_{i j}$

$j=1,2, \ldots, n$

$4 \quad \sum_{i}\left(P_{i}+C_{i j}\right) x_{i j} \leq B_{j}$

$i=1,2, \ldots, n$

$j=1,2, \ldots, n$

$5 \quad\left(P_{i}+C_{i j}\right) x_{i j} \leq P_{k}+C_{k j}$

$j=1,2, \ldots, n$

$i=1,2, \ldots, n$

$k=1,2, \ldots, n$

$j=1,2, \ldots, n$

$6 \quad\left(t_{i j}\right) x_{i j} \leq t_{k j}$

$i=1,2, \ldots, n$

$k=1,2, \ldots, n$

$7 \quad \lambda_{i}=\sum_{j} \gamma_{j} x_{i j}$

$i=1,2, \ldots, n$

$8 \quad \operatorname{Pr}\left(L_{i} \leq z\right) \geq \alpha$

$i=1,2, \ldots, n$

$9 \quad a_{i} y_{i} \leq P_{i} \leq b_{i} y_{i}$

$i=1,2, \ldots, n$

$10 y_{i}=\{0,1\}$

$i=1,2, \ldots, n$

11

$$
x_{i j}=\{0,1\}
$$

$j=1,2, \ldots, n$

$i=1,2, \ldots, n$

\section{4-2- Explanation of aim function and limitations}

Equation 1 introduces the function of the problem's aim, which is to maximize the price of products and minimize the expense of establishing sales centers, as well as minimizing the cost of sending goods from the central storage to the branches. Limitation 2 indicates the purchase of each customer will be done only from one sales center. Limitation 3 states that if sales are to be made through a specific point, then the store must have already been established in the point. Limitation 4 is related to the limitation of customers' budget, which includes the cost of transportation and the price of the goods. Limitation 5 ensures that the customer 
purchase from where that has the lowest cost. In the other words, limitation 5 is limitation 4 , with the difference that it considers the minimum transportation charge for each customers, in other words, this limitation ensures that the transportation each customer performs is optimal and buy from the nearest branch. Limitation 6 is related to the time of customer's transportation and seeks a combination that, in general, customers take the shortest time to buy a product. Limitation 7 indicates the method of calculating the demand rate for each region. Limitation 8 indicates the probability that the queue length is less than a specified value is at least $\alpha$. limitation 9 states that the price has a high and low limit and, finally, limitation 10 and 11 indicate the variables $\mathrm{x}$ and $\mathrm{y}$ are zero and one and shows how to calculate the delivery time for each trip, which is equal to the lowest delivery time for the orders that have been assigned to that trip.

Based on the model provided by Marianov and Serra, limitation 7 can be rewritten as follows:

$$
\operatorname{Pr}(L \leq z) \geq \alpha==\sum_{j} \gamma_{j} x_{i j} y_{i} \leq \sqrt[z+2]{1-\alpha \mu_{\mathrm{i}}}
$$

The above unequal assumptions can be provided as follows:

- In each branch that is being built, there is only one server.

- The branches are independent of each other.

- The queuing service in each branch follows the M / M / 1 model.

-In the case of the probability distribution function, exponential distribution function has been used.

\section{4-3 - Developing the issue model based on an stable model (Mulvey)}

In the certain model which is presented, the rate of demand for purchasing product is considered fix, which in real condition it is impossible. Because the rate of demand for a product depends on season, technology development, closeness to special days such as New Year.

In this research we use the Mulvey model and the approach of stable modeling for the purpose of evaluating the function of model in an unfixed condition. The Mulvey approach is the approach of using the concept of stability for optimization. In his model he introduced two types of variables. Control variables and designing variables. Also limitations divided to structural and control types. On this base four considered scenario for demand is different for our products (24). According to this base the model of issue is rewritable as below. It should be 
mentioned that in this model pmean shows the average of whole price, $\lambda$ is shows the rate of customer's entrance to branch $i$ and in the event $s$ and prs shows the probability of happing of the event $\mathrm{S}$.

$$
\begin{aligned}
& 12 \min \mathrm{z}=\beta \cdot\left(\sum_{s} \sum_{i} p r_{s} \cdot p_{i} \cdot \lambda_{i s}\right)+(1-\beta)\left(\sum_{s} \sum_{i} p r_{s} \cdot\left(\text { pmean }-p_{i} \cdot \lambda_{i s}\right)^{2}\right. \\
& 13 \text { pmean }=\sum_{s} \sum_{i} p r_{s} \cdot p_{i} \cdot \lambda_{i s} \\
& 14 \sum_{i} x_{i j} \leq 1 \\
& j=1,2, \ldots, n \\
& 15 y_{i} \geq x_{i j} \\
& j=1,2, \ldots, n \\
& i=1,2, \ldots, n \\
& 16 \sum_{i}\left(P_{i}+C_{i j}\right) x_{i j} \leq B_{j} \\
& j=1,2, \ldots, n \\
& j=1,2, \ldots, n \\
& 17\left(P_{i}+C_{i j}\right) x_{i j} \leq P_{k}+C_{k j} \\
& i=1,2, \ldots, n \\
& k=1,2, \ldots, n \\
& j=1,2, \ldots, n \\
& 18\left(t_{i j}\right) x_{i j} \leq t_{k j} \\
& i=1,2, \ldots, n \\
& k=1,2, \ldots, n \\
& 19 \lambda_{i}=\sum_{j} \lambda_{j} x_{i j} \\
& i=1,2, \ldots, n \\
& 20 \sum_{j} \gamma_{j} x_{i j} y_{i} \leq \sqrt[z+2]{1-\alpha \mu_{i}} \\
& j=1,2, \ldots, n \\
& 21 a_{i} y_{i} \leq P_{i} \leq b_{i} y_{i} \\
& i=1,2, \ldots, n \\
& 22 y_{i}=\{0,1\} \\
& i=1,2, \ldots, n \\
& 23 \quad x_{i j}=\{0,1\} \\
& j=1,2, \ldots, n \\
& i=1,2, \ldots, n
\end{aligned}
$$

\section{4-4 - Tabrid's Simulated Algorithm}

Tabrid's simulated Algorithm is one of the famous over creative methods for solving the issues of optimizing, which its main idea is based on gradual cooling of the material. Tabrid's simulated Algorithm in every temperature, passes from an internal ring which involves some steps and in each step there is comparison between previous optimal aim of function and 
present optimal aim .In this research each of these step can be achieved by two methods of present optimal function and finally the best of these amounts will consider by function of aim in this step. The first method is the common way in Tabrid's simulated Algorithm and second method is Cycle of Hill Climbing. This cycle by regulating the movements between the adjacent parts, help to establish suitable structure in webs and majors. Although this method does not guarantee reaching the answer but can increase the speed of reaching the answer beside Tabrid's simulated Algorithm (25-26).

\section{5-Analysis of the results}

In this research 39 numeral examples will evaluated which among them 13 examples in small size (involving 10 potential locations), 13 examples in medium size( involving 20 potential locations )and 13 example in large size (involving 30 potential locations ). Among 39 solved examples in this research first three example as basic examples were defined and then by making less and more of parameters $\mathrm{z}, \mu \alpha$ which in order show maximum of queue length, cost of service in each branch and possibilities of not going out from the maximum queue length. Another 12 examples for each size issue will be made which each one in the amount of parameter is different from basic numeral example. For achieving the answer, because Algorithm acts accidently, each example will be solved three times by this algorithm and we consider the final answer, the average of these three answers .In the designing of basic examples of location demand's rate among integers 1 up to 7 have been chosen, and the number of 1 and 2 shoe less demand 3 and 4 show mediocre demand 5 and 6 show high demand. Also for calculating numbers of $\mu$ and $\mathrm{Lq}$ at first we calculate some amount by the title of $\chi$ by dividing location demands to one fourth of location numbers and consider it as a total $\lambda$ in system, then because in each queue system amount of $\lambda / \mu$ should be less than one, so we choose $\mu$ a large number from $\chi$. In continues we calculate length of the queue according to the queue system $\mathrm{M} / \mathrm{M} / 1$ and we consider the amount of $\mathrm{Z}$, one unit less. For achieving the answer, because the Algorithm of simulated Tabrid does accidently, we solve each example three times by this algorithm and consider the average of them as a final answer. Table number 1 shows numeral amount of three basic example parameters. 
Table 1

Amount of three basic example parameter

\begin{tabular}{|c|c|c|c|c|c|}
\hline \multicolumn{2}{|r|}{ Size of issue } & $\mathrm{a}_{\mathrm{i}}$ & $\mathrm{b}_{\mathrm{i}}$ & $\gamma_{\mathrm{j}}$ & fi \\
\hline 10 & $\begin{array}{c}201918 \\
16151314 \\
121015\end{array}$ & $\begin{array}{l}3430324035 \\
3030282824\end{array}$ & $\begin{array}{c}56 \\
45335 \\
421\end{array}$ & 6 & $\begin{array}{c}282726 \\
25232321 \\
212121\end{array}$ \\
\hline 20 & $\begin{array}{c}202020201919 \\
20181717181715 \\
1414143151312\end{array}$ & $\begin{array}{c}403535403938383 \\
73532333230302928 \\
21252522\end{array}$ & $\begin{array}{c}55 \\
66654 \\
55466 \\
65433 \\
211 \\
\end{array}$ & 7 & $\begin{array}{c}282827 \\
27262725 \\
25242424 \\
23232121 \\
21212020 \\
\end{array}$ \\
\hline 30 & $\begin{array}{c}202020201919 \\
20191918181717 \\
181716161615151 \\
41414131514131 \\
2118\end{array}$ & $\begin{array}{c}403838373636353 \\
54039383837353233 \\
30302928252524232 \\
22212121\end{array}$ & $\begin{array}{c}55 \\
66654 \\
55466 \\
64333 \\
23343 \\
22321 \\
121\end{array}$ & 6 & $\begin{array}{c}282827 \\
27262526 \\
26272525 \\
24242423 \\
23212322 \\
22212121 \\
20201920 \\
191919\end{array}$ \\
\hline
\end{tabular}

$\mathrm{a} i$ and $\mathrm{b} \mathrm{i}$ in order show the acceptable maximum and minimum for pricing in location i. yj, cost of location demand j, $\mathrm{Z}$ maximum length of the queue, $\mu$ cost of service in each location, $\alpha$ possibility of not passing from maximum acceptable length of queue and Fi cost of establishing branch in the location $\mathrm{i}$. The way of making other 12 examples was according to basic examples which three mentioned parameters in each three basic examples, according to table 2 make less or more, which the result is new 12 examples, that each one in the amount of one parameter is different from its basic number.

Table 2

Amount of different parameters in 39 numeral examples

\begin{tabular}{|c|c|c|c|c|c|}
\hline Size & number of group & issue & $\mathrm{Z}$ & $\mu$ & $\alpha$ \\
\hline \multirow{8}{*}{ small } & \multirow{8}{*}{10} & 1 & 6 & 18 & 9.0 \\
\hline & & 2 & 4 & 18 & 9.0 \\
\hline & & 3 & 5 & 18 & 9.0 \\
\hline & & 4 & 7 & 18 & 9.0 \\
\hline & & 5 & 8 & 18 & 9.0 \\
\hline & & 6 & 6 & 16 & 9.0 \\
\hline & & 7 & 6 & 17 & 9.0 \\
\hline & & 8 & 6 & 19 & 9.0 \\
\hline
\end{tabular}




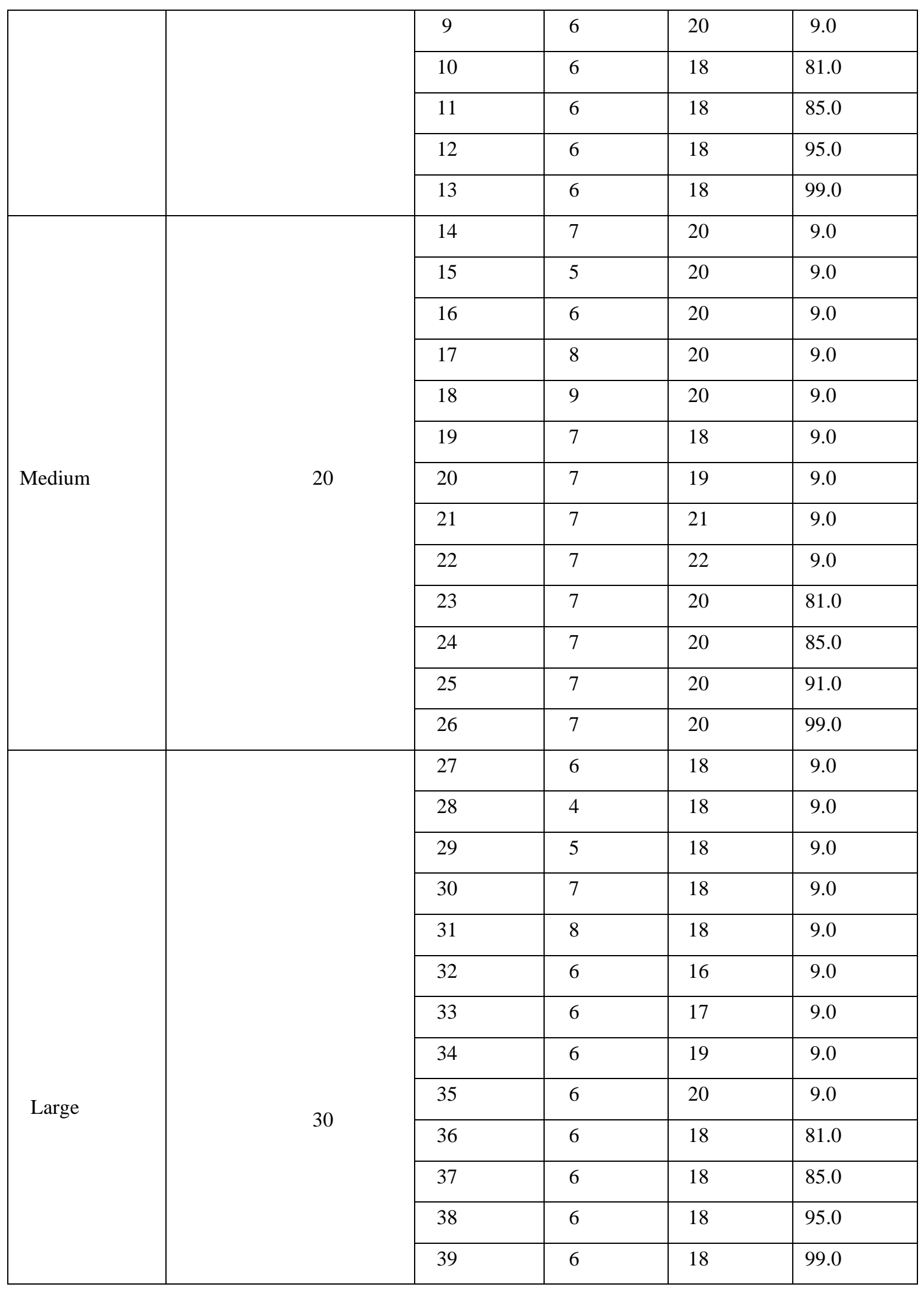




\section{5-1 solving numeral examples by Tabrid's simulated Algorithm}

At first for evaluating the correctness and competence of achieved answers by Tabrid's simulated Algorithm, issue is solved in small size by Lingo and its final answer is reached, then the answer was compared by the answer of Tabrid's simulated. For solving this 30 examples by Tabrid's simulated Algorithm, for arranging three parameters of T (first temperature) $\alpha$ ( rate of cooling) and (number of repetition of internal rings ), we pass two levels of arranging the parameters , which its first level of it is shown in below table :

\section{Table 3}

Average of aim function for each determined amount for the parameter of $\mathrm{T}$ in three sizes in the Tabrid's simulated algorithm

\begin{tabular}{|c|c|c|c|c|c|c|c|}
\hline$T$ & $\begin{array}{ll}80 & \\
& 0\end{array}$ & $\begin{array}{ll}9 & \\
& 00\end{array}$ & $\begin{array}{ll}1 & \\
& 000\end{array}$ & $\begin{array}{ll}1 & \\
& 100\end{array}$ & $\begin{array}{ll} & \\
& \\
& 200\end{array}$ & $\begin{array}{l}13 \\
00\end{array}$ & $\begin{array}{l}140 \\
0\end{array}$ \\
\hline $\begin{array}{r}\text { size } \\
10\end{array}$ & $\begin{array}{l}60 \\
\quad 23\end{array}$ & $\begin{array}{l}6 \\
118\end{array}$ & $\begin{array}{l}6 \\
328\end{array}$ & $\begin{array}{l}5 \\
\quad 655\end{array}$ & $\begin{array}{ll}6 & \\
& 73 \\
2 & \end{array}$ & $\begin{array}{l}67 \\
54\end{array}$ & $\begin{array}{c}669 \\
2\end{array}$ \\
\hline 20 & $\begin{array}{ll} & \\
& 96 \\
3 & \end{array}$ & $\begin{array}{ll} & \\
& 299 \\
2 & \end{array}$ & $\begin{array}{ll} & 1 \\
& 305 \\
& \end{array}$ & $\begin{array}{ll} & \\
& 315 \\
& \end{array}$ & $\begin{array}{ll}1 & \\
& 37 \\
& \\
1 & \\
& \\
& 4\end{array}$ & $\begin{array}{ll} & 13 \\
& 75 \\
& \end{array}$ & $\begin{array}{c}136 \\
54\end{array}$ \\
\hline 30 & $\begin{array}{ll} & 18 \\
& 46 \\
6 & \end{array}$ & $\begin{array}{ll} & \\
& 849 \\
& \end{array}$ & $\begin{array}{ll} & 1 \\
& 859 \\
& \end{array}$ & $\begin{array}{ll} & \\
& 902 \\
& \end{array}$ & $\begin{array}{ll}1 & \\
& 92 \\
& \\
5 & \\
& 6\end{array}$ & 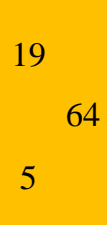 & $\begin{array}{c}195 \\
25\end{array}$ \\
\hline
\end{tabular}

Table 4

Average of aim function for determined amount for parameter $\alpha$ in three sizes in Tabrid simulated algorithm

\begin{tabular}{|c|c|c|c|c|c|c|}
\hline & 1.0 & 2.0 & 3.0 & 4.0 & 5.0 & 6.0 \\
\hline $\begin{array}{ll} & \\
& \end{array}$ & 5945 & 6856 & 6823 & 6129 & 5752 & 5532 \\
\hline 2 & 1306 & 1368 & 1365 & 1259 & 1287 & 1253 \\
\hline 0 & 5 & 9 & 6 & 5 & 2 & 2 \\
\hline 3 & 1833 & 1968 & 1970 & 1912 & 1895 & 1832 \\
\hline 0 & 2 & 2 & 2 & 1 & 2 & 3 \\
\hline
\end{tabular}




\section{Table 5}

Average of aim function for determined amount for the parameter $\mathrm{n}$ in three sizes in Tabrid's simulated algorithm

\begin{tabular}{|c|c|c|c|c|c|}
\hline size & 30 & 40 & 50 & 60 & 70 \\
\hline 10 & 6125 & 6233 & 6658 & 6749 & 6612 \\
\hline 20 & 13025 & 13165 & 13562 & 13689 & 13614 \\
\hline 30 & 18652 & 18686 & 19152 & 19025 & 19001 \\
\hline
\end{tabular}

In table 3 each of basic examples in small, medium, large sizes for being fix in amount of two parameters $\alpha$ and $\mathrm{n}$ with different amount of primary temperature, three times have been solved which their average is shown in table. In table 4 and 5 each of three basic examples for being fix in two other parameters, in order with different amounts $\alpha$ and $n$ have been solved and is shown in table. From given tables on top 8 scenarios are achieved in best form in each example.

$\dot{\alpha}=0.2,0.3$

$n=50,60$

$$
T=1200,1300
$$

Table 6

Eight scenarios evaluated for each basic examples, in second level or regulation of the parameter of Tabrid Simulated algorithm

\begin{tabular}{|c|c|c|c|}
\hline Number of scenario & $\mathrm{N}$ & $a$ & $\mathrm{~T}$ \\
\hline 1 & 50 & 2.0 & 1200 \\
\hline 2 & 50 & 3.0 & 1200 \\
\hline 3 & 60 & 2.0 & 1200 \\
\hline 4 & 60 & 3.0 & 1200 \\
\hline 5 & 50 & 2.0 & 1300 \\
\hline 6 & 50 & 3.0 & 1300 \\
\hline 7 & 60 & 2.0 & 1300 \\
\hline 8 & 60 & 3.0 & 1300 \\
\hline
\end{tabular}


In the second level of parameter regulation by solving each basic example also by considering each of these scenarios we will reach tables of 7,8,9 (as mentioned previously each of these examples in each scenario have been solved by this algorithm and shown numbers in tables are average of three achieved answers ).

Table 7

The average of aim function of basic example in small size in 8 scenario by Tabrid's simulated Algorithm

\begin{tabular}{|c|l|l|l|l|}
\hline $\begin{array}{c}\text { Number } \\
\text { of scenario }\end{array}$ & $\mathrm{N}$ & $\dot{\alpha}$ & $\mathrm{T}$ & Average answer \\
\hline 1 & 50 & 2.0 & 1200 & 6514 \\
\hline 2 & 50 & 3.0 & 1200 & 6800 \\
\hline 3 & 60 & 2.0 & 1200 & 5893 \\
\hline 4 & 60 & 3.0 & 1200 & 5966 \\
\hline 5 & 50 & 2.0 & 1300 & 5628 \\
\hline 6 & 50 & 3.0 & 1300 & 6845 \\
\hline 7 & 60 & 2.0 & 1300 & 6555 \\
\hline 8 & 60 & 3.0 & 1300 & 58236 \\
\hline
\end{tabular}

Table 8

Average of aim function of basic example in medium size in 8 scenario by Tabrid's simulated Algorithm

\begin{tabular}{|l|l|l|l|l|}
\hline $\begin{array}{c}\text { Number } \\
\text { of scenario }\end{array}$ & $\mathrm{N}$ & $\dot{\alpha}$ & $\mathrm{T}$ & Average answer \\
\hline 1 & 50 & 2.0 & 1200 & 12582 \\
\hline 2 & 50 & 3.0 & 1200 & 12025 \\
\hline 3 & 60 & 2.0 & 1200 & 12051 \\
\hline 4 & 60 & 3.0 & 1200 & 13852 \\
\hline 5 & 50 & 2.0 & 1300 & 13894 \\
\hline 6 & 50 & 3.0 & 1300 & 12052 \\
\hline 7 & 60 & 2.0 & 1300 & 12520 \\
\hline 8 & 60 & 3.0 & 1300 & 11620 \\
\hline
\end{tabular}


Table 9

The average of aim function of basic examples in large size in 8 scenario by Tabrid's simulated algorithm

\begin{tabular}{|c|l|l|l|l|}
\hline $\begin{array}{c}\text { Number } \\
\text { of scenario }\end{array}$ & $\mathrm{N}$ & \multicolumn{1}{|c|}{$\alpha$} & $\mathrm{T}$ & Average answer \\
\hline 1 & 50 & 2.0 & 1200 & 18265 \\
\hline 2 & 50 & 3.0 & 1200 & 17052 \\
\hline 3 & 60 & 2.0 & 1200 & 18594 \\
\hline 4 & 60 & 3.0 & 1200 & 16852 \\
\hline 5 & 50 & 2.0 & 1300 & 16942 \\
\hline 6 & 50 & 3.0 & 1300 & 18195 \\
\hline 7 & 60 & 2.0 & 1300 & 19015 \\
\hline 8 & 60 & 3.0 & 1300 & 18695 \\
\hline
\end{tabular}

As it is shown in three tables of 7,8,9, for examples in small size, scenario number 6 , for example in medium size, scenario number 5 , and for example in large size, scenario number 7 are the best. So for other 12 examples in every size, the suitable scenario has been considered, which each one has been solved three times by Tabrid's simulated Algorithm, and the average of achieved answers is shown in table number 10. Table 10 is average of aim function and the time of solving 39 examples for best scenario in every size in Tabrid's simulated algorithm by using data of case study.

The case study of this research is SELF CHECKOUT TECHNOLOGY. This technology provides a mechanism for customers to be able to have self-control in the process of shopping (Scan, Packaging, and Paying) in the store especially in chain stores. So using this system can help to decrease human force costs, prevents having long queue next to cashier and helps to go out of store sooner. All the parameters of this issue are achieved from statistics of modern Everest chain stores. 
Table 10:

Compared table of solving the issue by the Tabrid's simulated in comparison with the way of solving by Lingo

\begin{tabular}{|c|c|c|c|c|c|c|c|c|c|}
\hline \multirow{2}{*}{$\begin{array}{l}\mathrm{N} \\
\text { umber of } \\
\text { groups }\end{array}$} & \multirow[b]{2}{*}{ ssue } & \multirow[b]{2}{*}{$\mathrm{z}$} & \multirow[b]{2}{*}{$\mu$} & \multirow[b]{2}{*}{$\alpha$} & \multicolumn{2}{|c|}{ SA } & \multicolumn{2}{|c|}{ Lingo } & \multirow{2}{*}{$\%$} \\
\hline & & & & & $\bar{z}$ & $\bar{t}$ & Z & $\mathrm{t}$ & \\
\hline \multirow{13}{*}{5} & 1 & 6 & $\begin{array}{ll}1 & \\
& 8\end{array}$ & 9 & $\begin{array}{l}6 \\
\quad 300\end{array}$ & $\begin{array}{l}0: \quad 0: 3 \\
\quad 0: 3\end{array}$ & $\begin{array}{l}6 \\
\quad 300\end{array}$ & $\begin{array}{l}0: \\
\quad 1: 30\end{array}$ & $\begin{array}{l}0 . \\
\quad 00\end{array}$ \\
\hline & 2 & 4 & $\begin{array}{ll}1 & \\
& 8\end{array}$ & 9 & $\begin{array}{l}6 \\
801\end{array}$ & $\begin{array}{ll}0: & \\
& 0: 5\end{array}$ & $\begin{array}{l}6 \\
\quad 801\end{array}$ & $\begin{array}{l}0: \\
\quad 2: 35\end{array}$ & $\begin{array}{l}0 . \\
\quad 00\end{array}$ \\
\hline & 3 & 5 & $\begin{array}{ll}1 & \\
& 8\end{array}$ & $\begin{array}{ll}9 & \\
& .0\end{array}$ & $\begin{array}{l}7 \\
\quad 012\end{array}$ & $\begin{array}{l}0: \\
\quad 0: 6\end{array}$ & $\begin{array}{l}7 \\
\quad 010\end{array}$ & $\begin{array}{l}0: \\
\quad 1: 38\end{array}$ & $\begin{array}{l}0 . \\
\quad 03\end{array}$ \\
\hline & 4 & 7 & $\begin{array}{ll}1 & \\
& 8\end{array}$ & $\begin{array}{ll}9 & \\
& \end{array}$ & $\begin{array}{l}5 \\
\quad 725\end{array}$ & $\begin{array}{l}0: \\
\quad 0: 5\end{array}$ & $\begin{array}{l}5 \\
\quad 709\end{array}$ & $\begin{array}{l}0: \\
\quad 1: 48\end{array}$ & $\begin{array}{l}0 . \\
\\
28\end{array}$ \\
\hline & 5 & 8 & $\begin{array}{ll}1 & \\
& 8\end{array}$ & $\begin{array}{ll}9 & \\
& \\
& .0\end{array}$ & $\begin{array}{l}6 \\
\quad 312\end{array}$ & $\begin{array}{l}0: \\
\quad 0: 6\end{array}$ & $\begin{array}{l}6 \\
\quad 312\end{array}$ & $\begin{array}{l}0: \\
\quad 1: 53\end{array}$ & $\begin{array}{l}0 . \\
\\
\end{array} 00$ \\
\hline & 6 & 6 & $\begin{array}{ll}1 & \\
& 6\end{array}$ & $\begin{array}{ll}9 & \\
& \\
& .0\end{array}$ & $\begin{array}{l}6 \\
\quad 701\end{array}$ & $\begin{array}{l}0: \\
\quad 0: 4\end{array}$ & $\begin{array}{l}6 \\
693\end{array}$ & $\begin{array}{l}0: \\
\quad 1: 26\end{array}$ & $\begin{array}{l}0 . \\
\\
\end{array}$ \\
\hline & 7 & 6 & $\begin{array}{ll}1 & \\
& 7\end{array}$ & $\begin{array}{ll}9 & \\
& \\
& .0\end{array}$ & $\begin{array}{l}6 \\
\quad 321\end{array}$ & $\begin{array}{l}0: \\
\quad 0: 11\end{array}$ & $\begin{array}{l}6 \\
\quad 321\end{array}$ & $\begin{array}{l}0: \\
\quad 1: 42\end{array}$ & $\begin{array}{l}0 . \\
\quad 00\end{array}$ \\
\hline & 8 & 6 & $\begin{array}{ll}1 & \\
& 9\end{array}$ & $\begin{array}{ll}9 & \\
& \\
& .0\end{array}$ & $\begin{array}{l}5 \\
\quad 963\end{array}$ & $\begin{array}{l}0: \\
\quad 0: 8\end{array}$ & $\begin{array}{l}5 \\
\quad 963\end{array}$ & $\begin{array}{l}0: \\
\quad 2: 19\end{array}$ & $\begin{array}{l}0 . \\
\quad 00\end{array}$ \\
\hline & 9 & 6 & $\begin{array}{ll}2 & \\
& 0\end{array}$ & $\begin{array}{ll}9 & \\
& \\
& .0\end{array}$ & $\begin{array}{l}5 \\
\quad 812\end{array}$ & $\begin{array}{l}0: \\
\quad 0: 9\end{array}$ & $\begin{array}{l}5 \\
\quad 801\end{array}$ & $\begin{array}{l}0: \\
\quad 3: 12\end{array}$ & $\begin{array}{ll}0 . & \\
& 19\end{array}$ \\
\hline & 0 & 6 & 1 & $\begin{array}{ll}8 & \\
& 1.0\end{array}$ & $\begin{array}{l}6 \\
\quad 321\end{array}$ & $\begin{array}{l}0: \\
\quad 0: 10\end{array}$ & $\begin{array}{l}6 \\
318\end{array}$ & $\begin{array}{l}0: \\
\quad 3: 36\end{array}$ & $\begin{array}{l}0 . \\
\\
\end{array}$ \\
\hline & 1 & 6 & 1 & $\begin{array}{ll}8 & \\
& 5.0\end{array}$ & $\begin{array}{l}6 \\
\quad 972\end{array}$ & $\begin{array}{l}0: \\
\quad 0: 9\end{array}$ & $\begin{array}{l}6 \\
\quad 968\end{array}$ & $\begin{array}{l}0: \\
2: 58\end{array}$ & $\begin{array}{l}0 . \\
\quad 06\end{array}$ \\
\hline & 1 & 6 & 1 & $\begin{array}{ll}9 & \\
& \\
& 5.0\end{array}$ & $\begin{array}{l}6 \\
612\end{array}$ & $\begin{array}{l}0: \\
\quad 0: 4\end{array}$ & $\begin{array}{l}6 \\
612\end{array}$ & $\begin{array}{l}0: \\
\quad 2: 42\end{array}$ & $\begin{array}{l}0 . \\
\quad 00\end{array}$ \\
\hline & 3 & 6 & 8 & $\begin{array}{l}9 \\
\quad 9.0\end{array}$ & $\begin{array}{l}6 \\
645\end{array}$ & $\begin{array}{l}0: \\
\quad 0: 8\end{array}$ & $\begin{array}{l}6 \\
640\end{array}$ & $\begin{array}{l}0: \\
\quad 4: 13\end{array}$ & $\begin{array}{l}0 . \\
\quad 08\end{array}$ \\
\hline \multirow{4}{*}{8} & 1 & 6 & 1 & $\begin{array}{ll}9 & \\
& \\
& .0\end{array}$ & $\begin{array}{l}5 \\
\quad 820\end{array}$ & $\begin{array}{l}0: \\
\quad 0: 12\end{array}$ & $\begin{array}{l}5 \\
\quad 815\end{array}$ & $\begin{array}{l}0: \\
\quad 5: 26\end{array}$ & $\begin{array}{l}0 . \\
\quad 09\end{array}$ \\
\hline & 2 & 4 & 1 & 9 & $\begin{array}{ll}5 & \\
& 912\end{array}$ & $\begin{array}{l}0: \\
\quad 0: 18\end{array}$ & $\begin{array}{l}5 \\
\quad 912\end{array}$ & $\begin{array}{l}0: \\
5: 16\end{array}$ & $\begin{array}{l}0 . \\
\quad 00\end{array}$ \\
\hline & 3 & 5 & 1 & 9 & $\begin{array}{l}6 \\
\quad 235\end{array}$ & $\begin{array}{l}0: \\
\quad 0: 15\end{array}$ & $\begin{array}{l}6 \\
\quad 235\end{array}$ & $\begin{array}{l}0: \\
5: 43\end{array}$ & $\begin{array}{l}0 . \\
\quad 00\end{array}$ \\
\hline & 4 & 7 & $\begin{array}{ll}1 & \\
& 8\end{array}$ & $\begin{array}{ll}9 & \\
& \\
& .0\end{array}$ & $\begin{array}{l}7 \\
\quad 852\end{array}$ & $\begin{array}{l}0: \\
\quad 0: 14\end{array}$ & $\begin{array}{l}7 \\
\quad 832\end{array}$ & $\begin{array}{l}0: \\
3: 33\end{array}$ & $\begin{array}{l}0 . \\
\\
\end{array}$ \\
\hline
\end{tabular}




\begin{tabular}{|c|c|c|c|c|c|c|c|c|c|}
\hline 5 & & 8 & $\begin{array}{l}1 \quad 8 \\
\end{array}$ & $\begin{array}{ll}9 & \\
& \\
& .0\end{array}$ & $\begin{array}{l}7 \\
\quad 652\end{array}$ & $\begin{array}{l}0: \\
\quad 0: 18\end{array}$ & $\begin{array}{l}7 \\
\quad 640\end{array}$ & $\begin{array}{l}0: \\
\quad 7: 41\end{array}$ & $\begin{array}{l}0 . \\
\quad 16\end{array}$ \\
\hline 6 & & 6 & $\begin{array}{ll}1 & \\
& 6\end{array}$ & $\begin{array}{ll}9 & \\
& .0\end{array}$ & $\begin{array}{l}9 \\
850\end{array}$ & $\begin{array}{l}0: \\
\quad 0: 12\end{array}$ & $\begin{array}{l}9 \\
850\end{array}$ & $\begin{array}{l}0: \\
\quad 6: 33\end{array}$ & $\begin{array}{l}0 . \\
\quad 00\end{array}$ \\
\hline 7 & & 6 & $\begin{array}{ll}1 & \\
& 7\end{array}$ & 9 & $\begin{array}{l}8 \\
\quad 756\end{array}$ & $\begin{array}{l}0: \\
\quad 0: 18\end{array}$ & $\begin{array}{l}8 \\
\quad 756\end{array}$ & $\begin{array}{l}0: \\
\quad 6: 48\end{array}$ & $\begin{array}{l}0 . \\
\quad 00\end{array}$ \\
\hline 8 & & 6 & $\begin{array}{ll}11 & \\
& 9\end{array}$ & 9 & $\begin{array}{l}8 \\
\quad 845\end{array}$ & $\begin{array}{l}0: \\
\quad 0: 25\end{array}$ & $\begin{array}{l}8 \\
830\end{array}$ & $\begin{array}{l}0: \\
\quad 7: 43\end{array}$ & $\begin{array}{l}0 . \\
\quad 17\end{array}$ \\
\hline 9 & & 6 & $\begin{array}{ll}2 & \\
& 0\end{array}$ & 9 & $\begin{array}{l}9 \\
\quad 856\end{array}$ & $\begin{array}{l}0: \\
\quad 0: 15\end{array}$ & $\begin{array}{l}9 \\
\quad 850\end{array}$ & $\begin{array}{l}0: \\
\quad 5: 18\end{array}$ & $\begin{array}{l}0 . \\
\quad 06\end{array}$ \\
\hline 1 & 0 & 6 & 1 & $\begin{array}{ll}8 & \\
& 1.0\end{array}$ & $\begin{array}{l}9 \\
\quad 652\end{array}$ & $\begin{array}{l}0: \\
\quad 0: 20\end{array}$ & $\begin{array}{l}9 \\
652\end{array}$ & $\begin{array}{l}0: \\
5: 29\end{array}$ & $\begin{array}{l}0 . \\
\quad 00\end{array}$ \\
\hline 1 & 1 & 6 & 1 & $\begin{array}{ll}8 & \\
& 5.0\end{array}$ & $\begin{array}{l}7 \\
586\end{array}$ & $\begin{array}{l}\text { 0: } \\
\quad 0: 19\end{array}$ & $\begin{array}{l}7 \\
586\end{array}$ & $\begin{array}{l}0: \\
\quad 4: 19\end{array}$ & $\begin{array}{l}0 . \\
\quad 00\end{array}$ \\
\hline 1 & 2 & 6 & 1 & $\begin{array}{ll}9 & \\
& 5.0\end{array}$ & $\begin{array}{l}7 \\
\quad 021\end{array}$ & $\begin{array}{l}0: \\
\quad 0: 17\end{array}$ & $\begin{array}{l}7 \\
\\
\end{array} 021$ & $\begin{array}{l}0: \\
\quad 6: 15\end{array}$ & $\begin{array}{l}0 . \\
\quad 00\end{array}$ \\
\hline 1 & 3 & 6 & 1 & $\begin{array}{l}9 \\
\quad 9.0\end{array}$ & $\begin{array}{l}7 \\
\quad 065\end{array}$ & $\begin{array}{l}0: \\
\quad 0: 19\end{array}$ & $\begin{array}{l}7 \\
\\
\end{array} 060$ & $\begin{array}{l}0: \\
\quad 5: 10\end{array}$ & $\begin{array}{l}0 . \\
\quad 07\end{array}$ \\
\hline
\end{tabular}

As it is shown in table 10, presented method of Tabrid's simulated is very suitable and in short time, in comparison with Lingo software, can recognize similar answers (even in better condition).

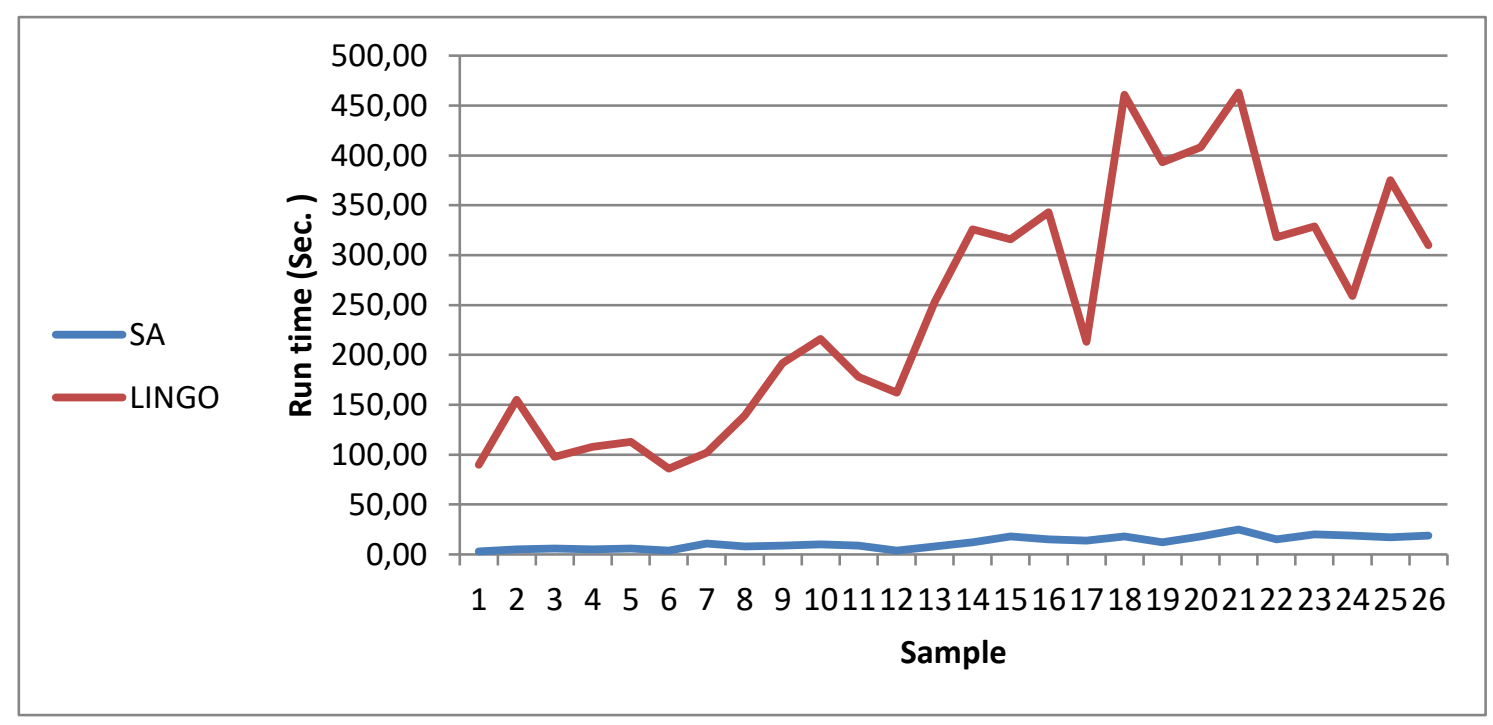

Picture 1: compared diagram of Tabrid's simulated with Lingo by considering time 


\section{Conclusion and presenting the future suggestions}

In this research, we studied about the issue of finding location and pricing. Presented model follows the aim of increasing of complex's profit. In the collection of potential locations, some of them are chosen for establishing branches, to be able to answer the demands in all these potential locations. We suppose that each customer has ability of paying the costs of traveling and price of the product, also they want to decrease the cost of these two. Pricing in each of these locations should be done in an acceptable price limitation, also in all of the locations the length of the queue should not be out of normal form .For the purpose of evaluating the competence and quality of presented Tabrid's simulated, some issues in some small samples by the software of Lingo in the best form were solved.And the results were compared by method of Tabrid's simulated. About researches which can be done in future, it can be said that because waiting in queue decrease the satisfaction of customers and in long time decreases demand and income, so decreasing the issue of waiting in queue in both cases time and length, can consider as a aim and should be paid attention in aim function. Also we can use the system of queue such as $\mathrm{M} / \mathrm{M} / \mathrm{C}$, also can do pricing and giving different products at the same time.

\section{References}

Abdullah Dasci, and Gilbert Laporte .(2004), Location and Pricing Decisions of a Multistore Monopoly in a Spatial Market, Journal of Regional Science, 44(3), 489-515.

Aboolean, R., O. Berman, and D. Krass. (2008), Optimizing pricing and locations for competitive service facilities charging uniform price, J. Oper. Res. Society 59(11), 15061519.

Arentze et al. (2007), Congestion pricing scenarios and change of job or residential location: Results of a stated adaptation experiment, Journal of Transport Geography, 15(1), 56-61.

Armin Lüer-Villagra, Vladimir Marianov. (2013), A competitive hub location and pricing problem, European journal of operational research, 231(3), 734-744.

Chu \& Lu. (1998), The multi-store location and pricing decisions of a spatial monopoly, Regional Science and Urban Economics,28(3), 255-281.

Eiselt, H. A., G. Laporte, and J. -F. Thisse. (1993), Competitive location models: Aframework and bibliography, Transportation Science, 27(1), 44-54.

Fernández et al. (2014), Location equilibria for a continuous competitive facility location problem under delivered pricing, Computers and Operations Research, 41, 185-195.

Fischer, K. (2002), Sequential discrete p-facility models for competitive location planning, Annals Oper. Res. 111, 253-270. 
Frank Plastria, Lieselot Vanhaverbeke. (2008), Maximal covering location problem with price decision for revenue maximization in a competitive environment.

Hansen, P. and N. Mladenovic. (2001), Variable neighborhood search, EuropeanJ. Oper. Res. 130, 449-467.

Hamjoul, P., P. Hansen, P. Peeters, and J. -F. Thisse. (2001), Uncapacitated plant location under alternative spatial price policies, MarketSci. 36, 41-57.

Hotelling, H. (1929), Stability in competition, Economic Journal 39, 41-57.

Hosun Rhima, Lee G. Cooperb. (2005), assessing potential threats to incumbent brands: New product positioning under price competition in a multi segmented market, Intern. J. of Research in Marketing, 22, $159-182$.

Kochetov, Yu. E. Alekseeva. (2005) T. Levanova, and M. Loresh, Large neighborhood local search for the p-median problem, Yugoslav J. Oper. Res, 15, 53-63.

Lederes, P. J. and J. -F. Thisse. (1990), Competitive location on network under delivered pricing Oper. Res. Letters, 9, 147-154.

Lopez et al. (2012), Location and contract pricing of distributed generation using a genetic algorithm, International Journal of Electrical Power \& Energy Systems, 36(1), 117-126.

Mahmood Zangui, Yafeng Yin., Siriphong Law phong panich, Shigang Chen. (2013), Differentiated Congestion Pricing of Urban Transportation Networks with Vehicle-Tracking Technologies, 36,434-445.

Naveen Khanna and. (2005), Pricing, exit, and location decisions of firms: Evidence on the role of debt and operating efficiency, Journal of Financial Economics, 75(2), 397-427.

Pacheco Pires. (2005), constrained efficient locations under delivered pricing, Regional Science and Urban Economics, 35(1), 49-56.

Peter et al. (2004), the effect of multi-purpose shopping on pricing and location strategy for grocery stores, Journal of Retailing, 80, 85-99.

Peter T. L. Popkowski Leszczyc a, Ashish Sinha b, Anna Sahgal. (2004), The effect of multipurpose shopping on pricing and location strategy for grocery stores, Journal of Retailing 80, 85-99.

Pierre Hansen, Dominique Peeters and Jacques-François. (1997), Facility Location under Zone Pricing, Regional Science Research Corporation, 37(1), 1-22.

Qian Candy Tang et al. (2005), optimal location and pricing of Web services intermediary, Decision Support Systems - Special issue: Web services and process management, 129 141

Teimoury, E., Hashemi Amiri, S. O., Ketabchi, F. (2018), Incorporating Vehicle Routing, Location and Supplier Selection Problems for Reducing Pollutants Emission, Industrial Engineering \& Management Systems, 16(4), 574-589.

Wang et al. (2004), Locating and pricing park-and-ride facilities in a linear monocentric city with deterministic mode choice, 38(8), 709-731.

Yue Zhang. (2015), Designing a retail store network with strategic pricing in a competitive environment, International Journal of Production Economics, 159,265-273. 